\title{
Ergonomic Diagnosis of a Ceramic Industry: A Case Study Using Couto's Checklist
}

\author{
Felipe Moreira Caland Bastos, Pedro Américo Orsano de Sousa, and Hélio Cavalcanti Albuquerque \\ Neto
}

\begin{abstract}
The ceramic industry has manufactured activities which require great physical effort on the part of its employees, enabling the appearances of Work-Related Musculoskeletal Disorders. Therefore, this article aims to realize the ergonomic diagnosis of a ceramics industry in the city of Teresina/Brazil. In this way, visits were carried out to this industry, applying the Couto's checklist to perform a biomechanical characterization of the labor sector, linking the possible musculoskeletal risks. The results showed that brick and tile catcher offer a great potential for musculoskeletal risks to their workers, while other sectors have virtually no risks. Therefore, some mitigation measures are suggested, as well as an overview of future steps for ergonomic improvement of the study target company.
\end{abstract}

Index Terms-Work-related musculoskeletal disorders, ceramic industry, couto checklist.

\section{INTRODUCTION}

Musculoskeletal disorders are extremely common among developed and undeveloped countries, causing different levels of functional incapacity to workers [1], [2] due to the fact these often execute moves with considerable rate of repetitiveness and physical effort. Such disorders are source of studies performed by some researchers, being named in the literature by Work-Related Musculoskeletal Disorders (WRMSD) [3]-[7]. The WRMSD symptoms can appear immediately or hours, days, months or even years later through continuous exposition [8] from centralized pains in the affected body area, resulting in complaints by workers to their employers. From the complaint recurrence, those workers are considered as a problem for their managers [9] concerning the probable lack of productivity.

Among the various sectors of existing tangible goods, the ceramics industry is part of that context, since a few of them are mechanized and has processes based on manual material handling, which consist of various activities including lifting, lowering, pushing, pulling and carrying [10]. Aiming to reduce such issue, it is important that the occupational safety professionals acquire greater knowledge about the performed work [11], emerging the necessity of ergonomics studies since it provides one of the main deliveries concerning work conditions [12]. Furthermore, this study allows verifying the situation of current labor outlook, identifying the issue's

Manuscript received May 31, 2015; revised October 12, 2015.

F. C. M. Bastos and P. A. O. de Sousa are with the Department of Industrial Engineering in the Federal University of Piaui, Teresina-PI-Brazil (e-mail: fmcb88@gmail.com,pedro_aamerico@hotmail.com).

H. C. Albuquerque Neto is with the Department of Industrial Engineering in the Federal University of Piauí, Teresina 80309 Brazil (e-mail: helio@ufpi.edu.br). demand as well as glimpsing the dose-response relation of the potential WRMSD [13]. Hence, over the prism of ergonomics analysis, an between theory and practice concerning the WRMSDs can be conditioned through using checklists, whose major characteristic is verifying the processes without a questioning to worker.

There are plenty of checklists that stand out for their extreme relevance in the literature, including the Couto's checklist [14] which is quite widespread among the Brazilian Ergonomics outlook. This checklist was developed in order to identify, among other factors, the physical strain and repetitive movements, in which the hands and wrists are submitted [15]. Corroborating with this fact, Ferreira [16] points out that the method is a subjective instrument and simple assessment that allows the recognition of the possible risks related to work, such as musculoskeletal disorders of the upper limbs, through a note from various points which include an analysis of the work.

Faced with this, the Couto's checklist is divided into six items: physical overload (five sub-items), strength hands (four sub-items), posture at work (seven sub-items), job and static force (two sub-items), repeatability and organization of work (five sub-items) and working tool (two sub-items), where scores are settled "zero" and "one" for each sub-item [17]. It should be noted that at the end of the application there will be a sum of all responses and from the results and interpretation criteria establishes the degree of risk in which the worker is exposed, as shown in Table I.

\begin{tabular}{|c|c|}
\hline Score & Interpretation \\
\hline $0-3$ & Lack of biomechanical factors - NO RISK \\
\hline $4-6$ & Lower significance for biomechanical factor - NO RISK \\
\hline $7-9$ & $\begin{array}{l}\text { Biomechanical factor of moderate importance - } \\
\text { UNLIKELY BUT POSSIBLE RISK }\end{array}$ \\
\hline $10-14$ & Significant biomechanical factor - RISK \\
\hline 15 or more & $\begin{array}{l}\text { Higher significance for biomechanical factor - HIGH } \\
\text { RISK }\end{array}$ \\
\hline
\end{tabular}

Given the previous explanation, this article aims to apply the Couto's checklist in a ceramic industry, making the diagnosis of possible musculoskeletal disorders on their workers. It should be noted that even though there are several publications on the activities of the ceramics industry, all of them have focused on silicosis disease and none of them have addressed musculoskeletal problems [18], showing a gap in the literature which can support a better decision making 
process taken by the managers that may mitigate potential musculoskeletal disorders.

\section{METHODS}

The procedures adopted in this paper were divided into two phases: (A) Systematic research by scientific papers and (B) Application of Couto's checklist.

\section{A. Systematic Research by Scientific Papers}

In order to base the major theme of this paper, a systematic search of scientific publications was carried out. Those publications are located at scientific portals inserted into the MetaLib tool of Ex Libris $®$, which is a libraries compilation that includes the recent digital resources for electronic researches and access of classical documents [19]. Thereby, the researched portals are cited as follows: Academic Search Complete, Agricola Articles, ChemWeb, Business Source Complete, CiteSeerX, Compendex, Current Contents, Energy Citations Database, ERIC, Inspec, Library, Information Science \& Technology Abstracts (LISTA), MEDLINE, PsycArticles, PsycCRITIQUES, PubMED, SCOPUS, SourceOECD, TRIS Online, Web of Science e Zentralblatt MATH, ACM Digital Library, ACS Journals, AHA Journals, Annual Reviews, BioMed Central Journals, Cambridge Journals Online, ASCE, Directory of Open Access Journals (DOAJ), Emerald, Geological Society of America (GSA), Highwire Press, IEEE Xplore, Taylor and Francis, IOPscience Journals, MetaPress, nature.com, Oxford Journals, Royal Society of Chemistry, SAGE, SciELO, Science Magazine, ScienceDirect, SIAM, Scitation, SpringerLink, The Chronicle of Higher Education and Wiley Online Library.

After that, the keywords to perform the research were determined into three combinations: 1) tile AND musculoskeletal disorders; 2) ceramic AND musculoskeletal disorders; 3) brick AND musculoskeletal disorders. The combinations performed should be located in the abstract or the paper title (if not be possible to search the abstract), moreover represents the entire theme about ceramic industry. Finally, the research was held between 22th and 26th of March in the present year, being limited to published papers until the current year or the ones which have already been available online, in which wait for the effective publication.

In order to obtain a greater scientific criterion, the methods for primary screening were adopted as follows: 1) Selecting only scientific papers, excluding other kind of publications, such as: editorials, letters to the editor, conferences, memorials, definitions of encyclopedias, opinion articles and magazine articles; 2) Selecting scientific journals which have a process of peer review, as many scientists and editors believe that this is the best approach available to guarantee scientific quality [20].

The papers selected went through a new screening process which allows to discard and to quantify according to the following criteria: 1) unavailability for regarding; 2) repetition; 3) language which are not Portuguese, English, Spanish, French, Italian and German, due to the lack of author's fluency in other languages. The publications that don't fulfill those four criteria were excluded for further analysis. Subsequently, there was a series of eligibility criteria in order to characterize the existing papers. Such methods are: 1) verification of papers that do not have an empirical analysis; 2) papers that are bent for the ceramics industry; 3) articles using checklist or 4) questionnaires as data collection method. The difference between screening and eligibility criteria is the screening reefers about the basic characteristics of the article. On other hand, the eligibility needs to read the entire article for make considerations. Therefore, all these procedures allow characterizing the publications on the subject of literature, assisting in the structuring of this article.

\section{B. Application of Research Instruments}

The study was applied in a ceramic industry located in Teresina city (Brazil), which operates in the national market, once have obtained a nationwide certificate related to its product quality. This company is organized into departments, such as finances, human resources, sales, quality and manufacturing. In order to achieve the goal proposed by this paper, the industrial department was focused since it presents the majority of ergonomics problems. Therefore, the manufacturing process presented previously served as basis for the checklist execution. The checklist was executed through direct observations by the authors, who have enough experience related to the manufacturing process, having know-how to perform them properly.

The process begins when the track loader operator collects the raw material and moves it to a place where it will receive the addition of water and it will form a plastic mass. After that, the plastic mass is compacted into an extruder and it is forced to pass through a nozzle with an established format, resulting in extruded pieces (brick or tile) that have the dimensions and format desired. At last but not least, a brick or tile catcher collect the pieces and organize them into a wagon.

As soon as the wagons are full, the wagon pusher moves the pieces to dryers at temperatures of approximately 70 degrees Celsius that will proceed with the slow and gradual elimination of water. After that, the dried materials need to be burnt (sintering). The kiln loaders get the dry pieces and move them to the kilns, which will operate at elevated temperatures where the fusion of particles occurs and product acquires its final properties. Finally, the kiln unloaders will take the final products off the kiln and they will stock them in a pre-determined place.

\section{ANALYSIS OF RESULTS}

From the foregoing about the approach of the methodological procedures presented, it was possible to check and discuss the results of which are addressed below.

\section{A. Systematic Research by Scientific Papers}

After the conducted research, it has met a total of 78 scientific publications. However, nine publications provided no scientific support, remaining only 69 publications that went through the screening processes. From these, it was found that all of them were published in journals having a 
peer review process. In this sense, combinations of keywords it was found that "Brick AND musculoskeletal disorders" was the one that resulted in the largest number of responses, which can be proven by the presentation of Table II.

TABLE II: RESULTS OF COMBINATIONS OF KEYWORDS

\begin{tabular}{lll}
\hline Keywords & & \\
\hline tile AND & brick AND & ceramic AND \\
musculoskeletal & musculoskeletal & $\begin{array}{l}\text { musculoskeletal } \\
\text { disorders }\end{array}$
\end{tabular}

\section{Number of}

publications 7

return

43

19

On the initial results, there was the exclusion screening process indicated in the methodology which resulted in the data shown in Table III.

TABLE III: RESULT OF THE EXCLUSION CRITERIA

\begin{tabular}{ll} 
Exclusion criteria & $\begin{array}{l}\text { Number of papers excluded } \\
\text { by criterion }\end{array}$ \\
\hline Unavailable articles for reading & 1 \\
Repeated articles & 46 \\
$\begin{array}{l}\text { Articles which are not written in } \\
\text { language that the authors did not have } \\
\text { fluency }\end{array}$ & 2 \\
\hline \hline
\end{tabular}

According to the data shown in Table 3 , there is only 1 article unavailable for reading, which does not compromise the characterization of the published literature concerning the issue under review. Furthermore, 2 articles are written in the Persian language in which the authors do not have creep causing them to be excluded from the analysis. In another aspect, there is a significant number of repeated articles (46) equivalent to more than half of all eligible items for the screening process (69), noting that there are few publications in the literature and that probably these are indexed in different databases. Therefore, the remaining articles (21) which can be characterized by the eligibility criteria are denoted in Table IV.

TABLE IV: RESULT OF THE ELIGIBILITY CRITERIA

\begin{tabular}{ll}
\hline Eligibility criteria & $\begin{array}{l}\text { Number of papers } \\
\text { eligibility by criterion }\end{array}$ \\
\hline $\begin{array}{l}\text { Papers that do not have an empirical } \\
\text { analysis }\end{array}$ & 5 \\
$\begin{array}{l}\text { Papers that are bent for the ceramics } \\
\text { industry }\end{array}$ & 4 \\
$\begin{array}{l}\text { Articles using questionnaire as data } \\
\text { collection method }\end{array}$ & 10 \\
$\begin{array}{l}\text { Articles using checklist as data collection } \\
\text { method }\end{array}$ & 2 \\
\hline \hline
\end{tabular}

Table IV establishes that five articles have no empirical data in their analyses, in which four are literature reviews and one is related to protocol validation. Moreover, four articles do not have focus in the ceramics industry in general, addressing to other sectors. Regarding the methods of data collection, ten articles performed questionnaires in which four are based on the Standardized Nordic Questionnaires proposed by Kuorinka et al. [21], being widely disseminated in the literature. Regarding the use of checklists, only two articles matched this criterion, where each one used two different methods: the MAC - Manual Handling Assessment Charts, which is a method that checks the stress caused by manual handling; and the RULA - Rapid Upper Limb Assessment, consisting of a checklist that verifies the movements performed by the upper limbs, classifying them according to the degree of risk.

Given these results presented previously, it is confirmed that there are few studies on musculoskeletal disorders in the ceramic industry, making this sector a niche to be exploited. Moreover, none of the articles used the Couto's checklist, confirming the importance of a study using this tool.

\section{B. Couto's Checklist Application}

Couto's checklist approaches the following parameters: 1) physical overload; 2) force with hands; 3 ) work posture; 4) static effort; 5) repetitiveness and organization and 6) work tools. Each parameter has different number of questions, which are answered by binary choices. Therefore, Table V represents the sum of answers for those parameters.

\begin{tabular}{|c|c|c|c|c|c|c|c|c|}
\hline Workstation & 1 & 2 & 3 & 4 & 5 & 6 & Sum & $\begin{array}{l}\text { Level of } \\
\text { Risk }\end{array}$ \\
\hline Kiln loader & 3 & 3 & 2 & 0 & 0 & 0 & 8 & possible risk \\
\hline Kiln unloader & 3 & 3 & 2 & 0 & 0 & 0 & 8 & possible risk \\
\hline $\begin{array}{l}\text { Extruder } \\
\text { operator (brick) }\end{array}$ & 1 & 0 & 1 & 0 & 0 & 0 & 2 & no risk \\
\hline Brick catcher & 3 & 3 & 4 & 0 & 4 & 0 & 14 & risk \\
\hline $\begin{array}{l}\text { Extruder } \\
\text { Operator (tile) }\end{array}$ & 1 & 0 & 1 & 0 & 0 & 0 & 2 & no risk \\
\hline Tile catcher & 3 & 3 & 4 & 0 & 4 & 0 & 14 & risk \\
\hline Wagon pusher & 3 & 2 & 3 & 0 & 0 & 0 & 8 & possible risk \\
\hline $\begin{array}{l}\text { Track Loader } \\
\text { operator }\end{array}$ & 2 & 0 & 1 & 0 & 0 & 0 & 3 & no risk \\
\hline
\end{tabular}

As it can be noticed, some workstations presented a relevant biomechanical factor, which indicates the necessity of immediate investigation on those workstations. Operations such as loading ovens require significant effort in order to remove bricks and tiles from the wagon into the kilns. Physical overload and force with hands have major 
representative to their high scores due to the handling of heavy materials.

Other critical workstations are tile and brick catchers since those workers have to reach the extruded products and put them in the wagons where the high level of repetitiveness of moving arms back and forth creates a poor working condition. Couto's checklist results pointed for greater scores on work posture and repetitiveness.

At last but not least, pushing wagons loaded with bricks and tiles demands odd postures with the low back bent, to name a few. Concerning this, the score for that workstation was 8 , where physical overload and work posture were the major problems, requiring immediate investigation on a biomechanical factor with moderate importance. Meanwhile, extruders and track loader operators have absence of biomechanical factors, since those functions are executed seated and don't present major problems on the six parameters.

\section{CONCLUSION}

The Couto's checklist notes that there is a great musculoskeletal risk potential for brick and tile catcher due to the intense physical effort, operating repeatability and postures. Moreover, other sectors have no potential risks, however, a number of measures can be adopted such as:

- Implementation of gymnastics during working hours in order to minimize and prevent musculoskeletal problems;

- Execution of periodic evaluation of the working methods in the various sectors, seeking ergonomic indicators that can help resize the production processes;

- Capacity building and training of workers for the development of a (re)ergonomic education, seeking to make them aware of the importance of adequate postures in the workplace.

- It is emphasized that the modernization of industrial processes enhances the minimization of physical efforts, however due to the financial burden of the industry, this proposed is temporarily discarded.

- According to the limitations of this paper, it can be cited the lack of time to implement the recommendations since this work was carried out by authors who had to direct synergistic efforts for other academic activities. Moreover, there were few visits to the industry due to the distance to university and the demand for a high-ranking employee who could orientate during the visits.

- For future works, it is recommended that future researches make comparisons between the Couto's checklist and other musculoskeletal disorders analysis tools, which are checklists or questionnaires. This comparison enables checking the points of congruence that the tools have in common, as well as further characterize the sector.

\section{REFERENCES}

[1] P. M. Brooks, "The burden of musculoskeletal disease - A global perspective," Clinical Rheumatology, vol. 25, pp. 778-781, 2006.
[2] T. S. B. S. Magnago, M. T. L. Lisboa, I. E. O. Souza, and M. C. Moreira, "Distúrbios musculo-esqueléticos em trabalhadores de enfermagem: Associação com condições de trabalho," Revista Brasileira de Enfermagem, vol. 60, no. 6, pp. 701-705, 2007.

[3] F. Serranheira, A. de S. Uva, and J. Espirito-Santo, "Estratégia de avaliação do risco de lesões músculo-esqueléticas de membros superiores ligadas ao trabalho aplicada na indústria de abate e desmancha de carne em Portugal," Revista Brasileira de Saúde Ocupacional, vol. 34, no.119, pp. 58-66, 2009.

[4] F. Serranheira and A. de S. Uva, "LER/DORT: Que métodos de avaliação do risco?" Revista Brasileira de Saúde Ocupacional, vol. 35, no. 122 , pp. $314-326,2010$.

[5] A. C. de S. Melzer and A. M. Iguti, "Working conditions and musculoskeletal pain among Brazilian pottery workers," Cadernos de Saúde Pública, vol. 26, no. 3, pp. 492-502, 2010.

[6] L. R. Inbaraj, O. J. Haebar, F. Saj, S. Dawson, P. Paul, A. K. P. Prabhakar, V. R. Mohan, and R. G. Alex, "Prevalence of musculoskeletal disorders among brick kiln workers in rural Southern India," Indian Journal of Occupational and Environmental Medicine, vol. 17, pp. 71-75, 2013.

[7] K. Pandey and A. Vats, "An owas-based analysis of workers engaged in brick making factories, faizabad district of uttar pradesh, india," Journal of Ergonomics, vol. 2, no. 2, 2012.

[8] N. Inyang, M. Al-Hussein, M. El-Rich, and S. Al-Jibouri, "Ergonomic Analysis and the Need for Its Integration for Planning and Assessing Construction Tasks," Journal of Construction Engineering and Management, vol. 138, pp. 1370-1376, 2012.

[9] I. A. P. Walsh, S. Corral, R. N. Franco, E. E. F. Canetti, M. E. R. Alem, and H. J. C. G. Coury, "Capacidade para o trabalho em indivíduos com lesões músculo-esqueléticas crônicas," Revista de Saúde Pública, vol. 38, n. 2, pp. 149-56, 2004.

[10] A. Dormohammadi, H. Amjad-Sardrudi, M. Motamedzade, R. Dormohammadi, S. Musavi, "A tile industry: A case of manual material handling," Journal of Research in Health Sciences, vol. 12, no. 2, pp. 109-113, 2012.

[11] V. Gouttebarge, H. Wind, P. P. Kuijer, J. K. Sluiter, and M. H. Frings-Dresen, "Construct validity of functional capacity evaluation lifting tests in construction workers on sick leave as a result of musculoskeletal disorders," Archives of Physical Medicine and Rehabilitation, vol. 90, pp. 302-308, 2009.

[12] A. Azadeh and M. Sheikhalishahi, "An efficient taguchi approach for the performance optimization of health, safety, environment and ergonomics in generation companies," Safety and Health at Work, 2015 .

[13] G. Engholm and E. Holmstrom, "Dose-response associations between musculoskeletal disorders and physical and psychosocial factors among construction workers," Scandinavian Journal of Work Environment \& Health, vol. 31, no. 2, pp. 57-67, 2005.

[14] H. A. Couto, Ergonomia Aplicada ao Trabalho: Conteúdo báSico: Guia Prático, Belo Horizonte: ERGO Editora, 2007.

[15] V. M. de V. Ferreira, S. G. N. Shimano, and M. de C. R. Fonseca, "Fisioterapia na avaliação e prevenção de riscos ergonômicos em trabalhadores de um setor financeiro," Revista Fisioterapia e Pesquisa, vol. 16, no. 3, pp. 239-245, 2009.

[16] P. C. Ferreira, Avaliação ergonômica de algumas operações florestais no município de Santa Bárbara-MG. 61 f. Dissertação (Pós-Graduação em Meio Ambiente e Sustentabilidade) - Programa de Pós-Graduação do Centro Universitário de Caratinga, Caratinga, 2006.

[17] K. C. Janz and R. Bordin, “Avaliação dos riscos de desenvolvimento de doenças osteomusculares relacionadas ao trabalho, associados ao estado de ânimo, em funcionários da divisão de nutrição e dietética do complexo hospitalar da Santa Casa de Porto Alegre," Revista HCPA, vol. 25 , pp. 27-34, 2005.

[18] A. C. S. Melzer and A. M. Iguti, "Working conditions and musculoskeletal pain among Brazilian pottery workers," Cadernos de Saúde Pública, vol. 26, no. 3, pp. 492-502, 2010.

[19] Y. Zhonghua and H. Ling, "An investigate MetaLib usage by Chinese students in Loughborough University," Journal of Theoretical and Applied Information Technology, vol. 48, pp. 1403-1409, 2013.

[20] B. Barkokébas Jr, E. M. G. Lago, F. M. Cruz, and H. C. Albuquerque Neto, "Environmental risks: A systematic review," Occupational Safety and Hygiene II, 2014.

[21] I. Kuorinka, B. Jonsson, A. Kilbom, H. Vinterberg, F. Biering-Sorensen, G. Andersson, and K. Jorgensen, "Standardized Nordic questionnaires for the analysis of musculoskeletal symptoms," Applied Ergonomics, vol. 18, no. 3, pp. 233-237, 1987. 


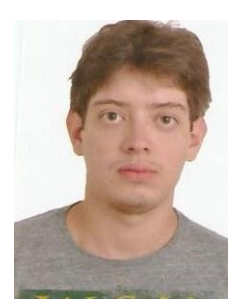

Felipe Moreira Caland Bastos was born in Teresina, Brazil on November 19, 1988. He finished his undergraduation in 2015, which majored in industrial engineering at Federal University of Piaui, located in Teresina-Piaui.

He has experience working as a quality analyst in a Call Center Company. Currently, he is a professor at the Industrial Engineering Department at Federal University of Piaui.

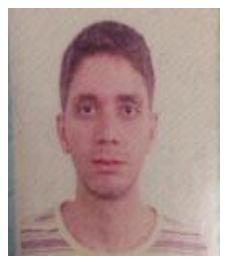

Pedro Américo Orsano de Sousa was born in Teresina, Brazil on February 23, 1991. He finished the high school at Institute Dom Barreto, Teresina in 2008. Then, in 2009, he started the under graduation degree of production engineering at Federal University of Piauí State (UFPI)

In 2013, he was enrolled in the sciences without borders program (SWB) and he started the under graduation sandwich in mechanical engineering at Lakehead University, Thunder Bay, Canada. As professional experience, in 2011 he was a intern at Mafrense Ltda. Currently, he is a intern at Icaraí Ltda, Teresina, Brazil. Mr. Sousa published the article entitled Nitriding of AISI 1020 steel: comparison between conventional nitriding and nitriding with cathodic cage (ISSN: 1516-1439).

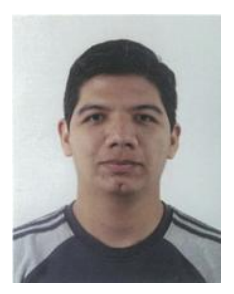

Hélio Cavalcanti Albuquerque Neto was born in Campina Grande, Brazil on August 23, 1985. He finished his undergraduation in 2010, which majored in industrial engineering at Federal University of Campina Grande, located in Campina Grande.

$\mathrm{He}$ is professor at industrial engineering department in Federal University of Piauí, having experience in Quality, Sustainability and Health and Safety.

Prof Albuquerque Neto is one editorial member of American Journal of Health Research and student of the Doctoral Program in Occupational Safety and Health, University of Porto, a researcher of the Group on Agro-industrial Processes and Products of Savannah and a member of the Research Laboratory of Applied Engineering and Production Economics, acting on the following subjects: Thermal environment, safety in construction industry and corporate sustainability. 